\title{
TV/Series
}

$2 \mid 2012$

Les séries télévisées dans le monde : Échanges, déplacements et transpositions

\section{... Paved with the Best Intentions? Utopian Spaces in Star Trek, the Original Series (NBC, 1966-1969)}

\section{Donna Spalding Andréolle}

\section{(2) OpenEdition}

\section{Journals}

Electronic version

URL: http://journals.openedition.org/tvseries/1376

DOI: $10.4000 /$ tvseries. 1376

ISSN: 2266-0909

Publisher

GRIC - Groupe de recherche Identités et Cultures

Electronic reference

Donna Spalding Andréolle, « ... Paved with the Best Intentions? Utopian Spaces in Star Trek, the Original Series (NBC, 1966-1969)», TV/Series [Online], 2 | 2012, Online since 01 November 2012, connection on 20 April 2019. URL : http://journals.openedition.org/tvseries/1376 ; DOI : 10.4000/tvseries.1376

\section{(c) (i) (9)}

TV/Series est mis à disposition selon les termes de la licence Creative Commons Attribution - Pas d'Utilisation Commerciale - Pas de Modification 4.0 International. 


\title{
... Paved with the Best Intentions? Utopian Spaces in Star Trek, the Original Series (NBC, 1966-1969)
}

\begin{abstract}
This paper is an examination of the ways in which the science fiction series Star Trek of the 1960 s sheds light on a crucial moment in American history, the social context of which includes political turmoil and the questioning of mainstream values. The very structure of the episodes, often introduced by the captain's log giving a stardate and a summary of the current situation of the starship Enterprise's mission-in-progress, points to the exploratory traditions of the American nation built over an almost 300-year period of westward expansion. It is possible, then, to draw a parallel between the Enterprise's journeys through the universe in search of "strange new planets and civilizations" (dixit Kirk's voice in the credit scene) and the American quest for new lands needed to perpetuate the utopian project of democratic society first set into motion by the Puritans of New England in the 17th century. Indeed, throughout the three seasons Captain Kirk and his crew will beam down to numerous planets said to be, in the words of various characters, a "paradise". Yet most of these spaces have somehow gone wrong: mad Earthmen have become dictators, terrorized natives are controlled by dysfunctional computers, or apparently beautiful, luxuriant forests filled in fact with poisonous plants kill and maim any human naive enough to venture there. Several other episodes explore the theme of parallel worlds where the "evil" potential of the Federation is exposed: the most emblematic episode entitled "Mirror, Mirror" thrusts Kirk into a parallel universe in which the Federation is a barbaric wardriven empire. One can wonder, then, to what extent the series challenges the utopian roots of the American world-view, treating it as a thin veneer behind which darker intentions can be easily exposed.
\end{abstract}

$\mathrm{T}$ his article is my second look at the very famous Star Trek series of the $1960 \mathrm{~s}^{1}$ and an examination of the ways in which this science fiction series sheds light on a crucial moment in American history, the social context of which includes political turmoil and the questioning of mainstream values. The very structure of the episodes, usually introduced by the captain's log giving a stardate and a summary of the current situation of the starship Enterprise's missionin-progress, points to the exploratory traditions of the American nation built over an almost 300-year period of westward expansion and transformed in the twentieth century into an ideological crusade first abroad, then in outer space. Taking this cultural background into consideration in the "reading" of the series, it is possible to draw a parallel between the Enterprise's journeys through the universe in search of "strange new planets and civilizations" (dixit Kirk's voice in the credit scene) and the American quest for new lands and ideological

${ }^{1}$ My first paper on this subject was presented at the conference "The Woodstock Years" organized by the GRIC and held in Le Havre in September 2010, and is entitled "Beam me up Scotty, there's no intelligent life down here': The failed (counter)cultural message of Star Trek, the Original Series (1966-1969)", published in the electronic journal EOLLE, No. 1, 2012, p. 38-46, http://www.univ-lehavre.fr/ulh_services/-Revue-EOLLE-.html. 
spaces needed to perpetuate the utopian project of democratic society first set into motion by the Puritans of New England in the 17th century.

Indeed, throughout the three seasons Captain Kirk and his multi-ethnic crew (including First Officer Spock, an alien, a black female communications officer, Uhura, and an Asian navigational officer, Mister Sulu) will beam down to numerous planets said to be, in the words of various characters, a "paradise"; a total of 14 episodes of the 79 produced deal with such spaces, some with revealing titles such as "This Side of Paradise", "The Apple", "The Paradise Syndrome" and "The Way to Eden". Yet most of these spaces have somehow gone wrong: mad Earthmen have become dictators; terrorized natives are controlled by dysfunctional computers; or apparently beautiful, luxuriant forests - filled in fact with poisonous plants - kill and maim any human naive enough to venture there. Several other episodes explore the theme of parallel worlds where the "evil" potential of the Federation of Planets, a kind of futuristic structure which has replaced the United States, is exposed: the most emblematic episode, entitled "Mirror, Mirror" (2.332), thrusts Kirk into a parallel universe in which the Federation is a barbaric war-driven empire; in "The Enemy Within" (1.5) a glitch in the transporter system beams up not the Captain Kirk we know but an evil Captain Kirk, a sort of strange alter ego who has lost the leadership qualities of the "real" Kirk, who remains suspended in some parallel universe until the end of the episode. One can wonder, then, to what extent the series challenges the utopian roots of the American world-view, treating it as a thin veneer behind which darker intentions can be easily exposed. Because Star Trek constitutes a countercultural message offering criticism of mainstream American values of the 1960 s, I propose here to take a closer look at some of these utopian spaces to illustrate how the series comments (more or less subtly depending on the episode) on the American social model and its limits.

First and foremost Star Trek can be seen in the light of the utopian tradition and its diverse representations. Many of the Enterprise's adventures take its crew to what are described as "perfect worlds"; the viewer is shown that these places are ethereal cities where outward appearance points to a "god-like blissful existence [...] assured to the superman who proves victorious in the evolutionary struggle" to

\footnotetext{
2 The referencing standard for Star Trek episodes differs from current standard of beginning each season with episode 1 ; a total of 79 episodes were made and are referenced in this continuous fashion from 1 to 79 . It can also be noted here that the episodes for all three seasons were not even aired in the order in which they were produced, creating a certain number of troubling (for the viewer) inconsistencies in costumes, characters and characterization, particularly, but not exclusively, in the first half of season 1. See http://en.wikipedia.org/wiki/List_of_Star_Trek:_The_Original_Series_episodes.
} 
quote specialist Richard Gerber in Utopian Fantasy3. Indeed, in "Requiem for Methuselah" (3.74) and "The Cloud Minders" (3.76) highly evolved, nearly immortal humanoids dedicate their lives to knowledge and the arts (see Plate 1).
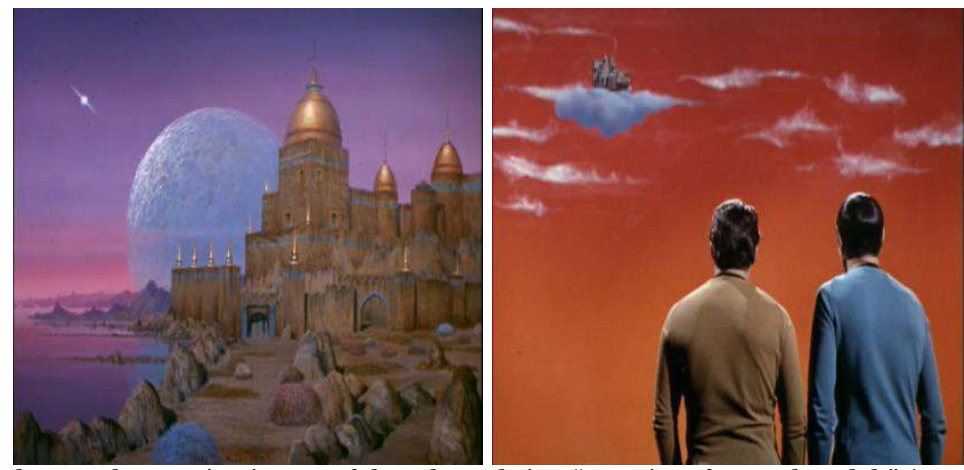

Plate 1: The utopian image of the ethereal city, "Requiem for Methuselah" (3.74) and "The Cloud Minders" (3.76)

Such an existence depends, however, on the subjugation of others: in the first case it is the Enterprise landing party who will be enslaved; in the second case it is a "subhuman" race used to mine the minerals needed to maintain the energy source for the city in the sky. For instance, in "The Cloud Minders", the first statements by Kirk and Spock as they land on the planet and observe the cloud city from the surface are remarks on the perfect nature of the culture on Stratos the floating city, dedicated entirely to art and intellectual pursuits (see Plate 1). However, after they have spent some time in the utopian space of the ethereal city, Kirk and Spock begin to question the validity of the planet's literal "two-tiered" system; the viewer is even treated to an (unusual) interior dialogue of Spock reflecting on the disparities of a utopian mode of life that at first seemed, even to him, to be a "paradise":

This troubled planet is a place of the most violent contrast. Those who receive the rewards are totally separated from those who shoulder the burdens. It is not a wise leadership. Here on Stratos everything is incomparably beautiful and pleasant; the high advisor's daughter Droxine, particularly so. I wonder, can she retain such purity and sweetness of mind and be aware of the life of the people on the surface of the planet? There, the harsh life is instilling the people with a bitter hatred. [...] If the lovely Droxine knew of the miners' misery, I wonder how the knowledge would affect her?

3 Richard Gerber, Utopian Fantasy: A Study of English Utopian Fiction since the End of the Nineteenth Century, London, Routledge \& Kegan Paul, 1955, p. 35. 
It will naturally be the Enterprise's role as the purveyor of Federation democracy to re-establish order in the chaos provoked by the revolt of the troglodyte miners against the slavery imposed upon them by the superior race of the ethereal city who depends in fact on the miners' production to maintain their culture of perfection. The references to the question of subjugation in the American utopian project are not even thinly veiled here, especially since in the larger social context of the viewing audience (1969 for Season 3 ) such issues remain at the center of countercultural rebellions, notably the Civil Rights Movement of the late 1950 s and early 1960 s as well as the anti-war movement and its denunciation of American oppression of the racial Other at home and in South-East Asia.

Conformity and compliance, important features of the utopian tradition the validity of which will be questioned in the twentieth century by the works of Aldous Huxley (Brave New World, 1928) and George Orwell (1984, 1948), are also extensively treated in Star Trek. In "Dagger of the Mind" (1.9), inmates of the Tantalus penal colony walk around like smiling zombies; but what Captain Kirk first perceives to be a "resort colony" rather than a prison is countered by Spock's observation that "[...] you Earth people glorify organized violence for forty centuries but you imprison those who employ it privately." Of course the viewer will discover later that compliance to this perfect environment is the product of a mind-altering machine used to torture prisoners into obedience, in a kind of futuristic model of Skinnerian negative reinforcement; it can be noted here that behavioral science was quite popular in the 1960 s, in particular thanks to B. F. Skinner's novel Walden II, first published in 1948 and which described a utopian community where happiness comes through conditioning. More importantly, this episode, like the third-season episode "The Cloud Minders", deals with the problem of violence and its necessary control in the quest for utopia. Here one cannot but look back to the political debate of the Framers of the U.S. Constitution on the role of "factions" (to use James Madison's words in Federalist Paper 104) and on the dilemma they posed - that is, if factions are allowed to disrupt, they are a threat to democracy, but muzzling or squashing them is antidemocratic in essence. In the highly technological societies of the Star Trek series, population control through mind-altering drugs or

\footnotetext{
4 Alexander Hamilton, John Jay and James Madison, The Federalist: A Commentary on the Constitution of the United States, ed. Robert Scigliano, New York, The Modern Library, 2000, p. 54: in the most famous paper of the collection, Madison (writing under the pseudonym "Publius") says, for example, "There are two methods of curing the mischiefs of faction: the one, by removing its causes; the other, by controlling its effects. There are again two methods of removing the causes: the one, by destroying the liberty which is essential to its existence; the other, by giving to every citizen the same opinions, the same passions, and the same interests."
} 
machinery remains at the crux of the utopian project and its "dark" undersides. Another example of this is in "The Return of the Archons" (1. 21), where the zombie-like behavior of the population of the planet Beta Three is later explained by the appearance of the mysterious godlike leader "Landru" whom the inhabitants seem to worship and who explains to the captive crew of the Enterprise the principles of utopian existence:

[The image of Landru appears on a wall in the crew's prison cell.]

LANDRU. I am Landru.

SPOCK. A projection, Captain. Not real.

KIRK. But beautiful, Mr. Spock, with no apparatus at this end.

LANDRU. You have come as destroyers. You bring an infection.

KIRK. You are holding my ship. I demand that you release it.

LANDRU. You have come to a world without hate, without fear, without conflict. No war, no disease, no crime: none of the ancient evils. Landru seeks tranquility, peace for all, the universal good.

KIRK. We mean you no harm. Ours is a mission of peace and good will.

LANDRU. The good must transcend the evil. It shall be done. So it has

been since the beginning.

SPOCK. He doesn't hear you, Captain.

KIRK. Landru, listen to me.

LANDRU. You will be absorbed. Your individuality will merge into the unity of good. And in your submergence into the common being and the body, you will feel contentment, fulfillment. You will experience the absolute good.

Here in the Skinnerian tradition (but also more generally in the utopian tradition in its modern interpretation), the necessary suppression of all that is fundamentally human, that is, not only negative traits like violence but also positive ones like agency, constitutes the only path to the peace and harmony in this apparently perfect world. That such perfection should come through the deployment of man's most sadistic tendencies seems to be beside the point. Again, in the modern utopian tradition these pseudo-utopias (which in fact are only the "masks" of dystopia) will be overturned or even destroyed thanks to the power of human agency, the example of which is most often supplied in the series by Captain Kirk and certain of his crew members, notably his two closest collaborators Mr. Spock, his pointy-eared alien First Officer and Dr. McCoy, the Enterprise medical officer. As Robert Elliott has said, "[Utopia] tends toward complete stasis. This has always been a problem for utopian writers, who have felt obliged to introduce conflict into their tales if they were to move at all. The usual device has been to import it from without: conflict, introspection, suffering, 'character,' usually arrive in Utopia with the visitor from outsides." Whereas in utopian writings the

${ }^{5}$ Robert Elliott, The Shape of Utopia: Studies in a Literary Genre, Chicago, The University of Chicago Press, 1970, p. 106. 
outsider habitually brings only disruption and destruction of the utopian world that he/she has unmasked as a less-than-perfect place, in Star Trek the Enterprise disrupts the flawed order but aids in the establishment of a new system, the seeds of a future utopia in the Federation tradition of peace and tolerance (but of which the viewer will not see the result).

Another typical dream of blissful existence is the return to the Garden of Eden, characteristic of the Arcadian tradition. Even 300 years into the future, Captain Kirk and his crew yearn for such spaces; quite a few of the planets explored throughout the series' three-year run begin with the idea that the planet being shown is a "paradise" of some sort. Yet as the viewer may come to suspect, most of these Gardens of Eden hold unpleasant surprises, as illustrated, for instance, in the episode "The Apple" (2.34): in the pre-credit scene which sets the action of the episode into motion (see Plate 2), while the landing party makes several remarks about the paradisiacal nature of the planet to which they have beamed down, one of the security guards is killed by a projectile from a seemingly harmless flower.
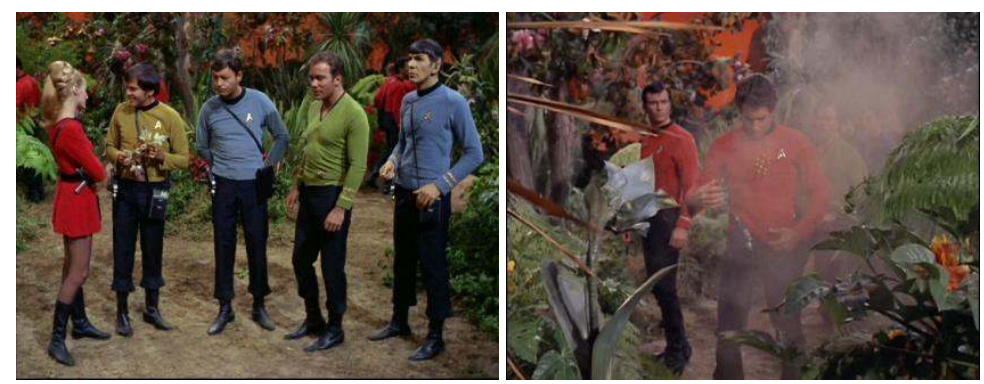

Plate 2: "The Apple" (2.34), in which the Enterprise crew takes in "paradise" while a flower kills a security guard by surprise

The dialogue is one of several passages which could be called "Cold War humor" in the series:

CHEKov. It makes me homesick. Just like Russia.

McCoY. More like the Garden of Eden, Ensign.

CHEKov. Of course, Doctor. The Garden of Eden was just outside Moscow. A wery [sic] nice place. It must have made Adam and Eve wery [sic] sad to leave.

KIRK. Just outside Moscow... All right!

As a closure to this dialogue, the security guard hit with poisonous darts from a flower calls out to Kirk before dying, after which the Captain muses to his crew but addressing the camera, "What did somebody say? That paradise must have looked like this?" - followed by dramatic music and a fade-out to the opening credit scene. It would 
thus seem that man continues to seek heavenly perfection, even in the far future, and that the underlying dangers of such desire still lead to man's fall but apparently not to the death of the utopian dream of paradise ${ }^{6}$. The rest of the episode progressively unveils the dystopic origin of the venomous Garden of Eden: the child-like inhabitants of the planet are maintained in a state of pre-Fall innocence (they have no sexual awareness, for example) by an alien computer whose programming has gone haywire, and who punishes them for any deviant behavior which includes, of course, any form of human agency or emotion. In the resolution scene, after Kirk and his crew have neutralized the computer and released the inhabitants from its grip, the chief of the group worries about the future of his people and is reassured by the paternalistic Kirk:

CHIEF. But it was Vaal who put the fruit on the trees, caused the rain to fall. Vaal cared for us.

KIRK. You'll learn to care for yourselves, with our help. And there's no trick to putting fruit on trees. You might even enjoy it. You'll learn to build for yourselves, work for yourselves, think for yourselves, and what you create is yours. That's what we call freedom. You'll like it, a lot. And you'll learn something about men and women, the way they are supposed to be: caring for each other, being happy with each other, being good to each other. That's what we call... love. You'll like that too, a lot. You, your children...

GIRL. What are children?

KIRK. The little ones, they look like you... just go on the way you're going, you'll find out!

[Natives all laugh as scene closes.]

Back on the Entreprise in the final scene, Spock argues that the Federation has given the inhabitants the equivalent of the Garden of Eden's apple (thus explaining the title of the episode), driving them out of paradise; but this disquieting thought is defused when Kirk and McCoy ask him who played the role of Satan while staring at Spock's pointy devil-like ears.

The theme of idyllic yet poisonous planets is treated in other episodes such as "The Way to Eden" (3.75) in which a group of cosmic hippies seek out the planet called Eden (by taking control of the Enterprise). Here the structure of the episode is focused on the quest for utopia itself, and the frame of the future utopian society is dictated by a charismatic leader, a certain Dr. Sevrin who has a galactic reputation in acoustic science. He is, however, the carrier of an infectious and fatal virus called Synthecoccus novae, ironically created

\footnotetext{
${ }^{6}$ According to Claude-Gilbert Dubois, although Utopia and Arcadia are not the same concepts, they both create an "unreal" framework because they are the result of the "worst artifices"; that is, the utopian and Arcadian imaginations do not change reality but are the negation of reality and its substitution with a subjective vision of the world. Claude-Gilbert Dubois, Problèmes de l'Utopie, Paris, Les Archives des Lettres Modernes, 1968, p. 25.
} 
by the technological society of the Doctor's home planet, making him the seed of destruction of the future perfect world he wants to found. And even though it is not this disease which will cause the utopian enterprise to fail in the end, Dr. Sevrin's affliction and its lethal potential point to the impending doom of the sought-after cosmic (hippie) commune. Indeed, Dr. Sevrin and his followers manage to hijack the Enterprise to find the mythical planet Eden, then steal a shuttle craft to reach the planet's surface before Kirk can stop them. Yet once the landing party beams down to Eden in pursuit of the hippies, they discover very quickly that all the plant life contains fatal levels of acid (Chekov tries to pick a flower and burns his hand severely). Kirk and his officers manage to find a few survivors with burned feet after having walked barefoot through the grass, but are unable to save others, including the character named Adam who symbolically dies after biting into a poisonous apple. It is not clear whether Gene Roddenberry, the executive producer of Star Trek, was making a specific comment on the demise of hippie-dom and the hip culture's antiquated fascination with the rural utopian model that led to the failure of many hippy communes in the late 196os, or if the intention is merely to question the utopian quest and the dangers it can hide.

A more specifically cultural look at paradise can be found in the episode "The Paradise Syndrome" (3.58), where the planet visited is inhabited by an American Indian tribe (see Plate 3); again, it is in the pre-credit scene that the landing party, made up of Kirk, Spock and McCoy, comments on the culture of the planet they have come to explore:

McCoy. Why, they look like... I'd swear they're American Indians.

SPOCK. They are, Doctor. A mixture of Navajo, Mohican and Delaware I believe. All among the more advanced and peaceful tribes.

KIRK. It's like discovering Atlantis.... Or Shangri La.....
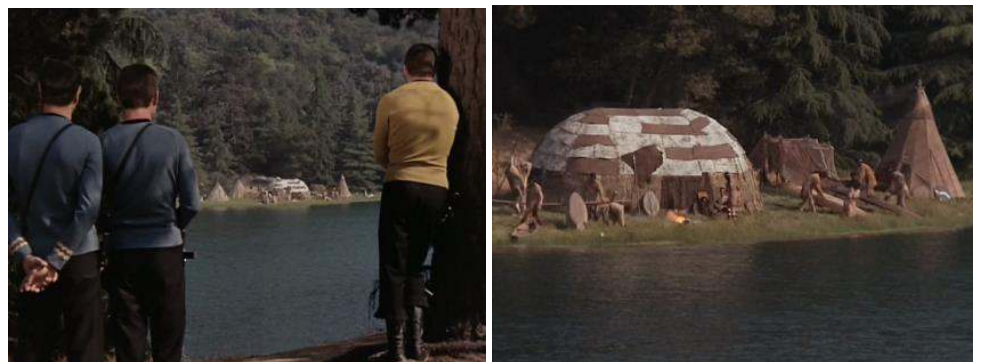

Plate 3: "The Paradise Syndrome" (3.58) - Landing party contemplates native culture, where a mixture of tribal artifacts can be noticed 
There is no explanation given of how such a mixture of tribes from the planet Earth could have found its way onto another planet in outer space, but the fact itself is not of major importance; what is to be noted, however, is that the most charming aspect of the native culture seems to be its primitive nature, representing as such a nostalgic "looking backward" (to borrow the title of Edward Bellamy's 1887 famous utopian novel) to a simpler time, so very characteristic of the 1960 s context of the series. Such nostalgia is further underlined in Spock's evaluation of this alien culture: he insists on the "peaceful" and "advanced" characteristics of the group while specifically relating these qualities to their tribal origins, an evaluation reflective of the fascination with Native American cultures typical of the counterculture. Along the same line of thought, the Enterprise crew, in the person of Captain Kirk, can only truly understand the beauty of this utopia by "forgetting" their own frame of reference: indeed, in this episode, Kirk becomes amnesic after falling inside a strange obelisklike structure built by an unknown (highly) advanced civilization and when he emerges from it he is believed to be a god by the local "primitives". Thus reborn, he lives the happy, simplistic life of the Indian tribe, falls in love with the Indian princess (in a futuristic remake of the Pocahontas tale) and is only brought back to his senses when Spock and McCoy beam down to get him just before an asteroid strikes the planet. Being torn from such bliss, by being brought back to the "reality" of the technological present, puts an end to Kirk's syndrome of desire for the paradise it will never be possible for him to obtain, at least permanently. So while this example, like "The Apple", demonstrates how the utopian genre can be employed in the telling of a cautionary tale, it more particularly illustrates the ambiguous nature of such spaces and the lessons that are to be learned about our yearning for some nostalgic, simpler time that can only be temporary at best and in the end cannot be anything but a disappointment.

Since Star Trek is, after all, a science fiction series, at the center of understanding its utopian spaces is the paradoxical nature of the American quest for the unknown; historically speaking, while technology lay at the very heart of westward expansion, new lands were described in terms of their natural, unspoiled beauty but were conquered in the name of the advancement of science and settled thanks to the introduction of technology. In the words of Leo Marx, "there is a special affinity between the machine and the new Republic. In the first place, the raw landscape is an ideal setting for technological progress [...]. In America progress is a kind of explosion7." Star Trek reiterates this paradigm of the (logical) clash of the machine in the garden. For example, in the episode entitled "A Private Little War"

7 Leo Marx, The Machine in the Garden: Technology and the Pastoral Ideal in America, Oxford, Oxford University Press, 2000 [1964], p. 202 (Kindle edition). 
(2.48), an allegory of the Cold War balance of power in third-world states, the arming by the Federation of the Hill People is seen as a necessary evil to maintain equal footing with the Villagers being armed by the Klingons; the introduction of advanced weaponry into the lowtech societies of both the Hill People and the Villagers by the high-tech cultures of the Federation and the Klingons is in fact described by McCoy as "the serpent in Eden". Other episodes attempt to treat the uneasy relationship between the technologically-driven culture of the Federation and the alien cultures encountered, or the misuse of technology for destructive purposes: in "The Changeling" (2.32), a rogue satellite annihilates entire populations when its programming perceives humans to be "biological infestations"; in "What are Little Girls Made Of?" (1.7), human life has been replaced by a mechanistic culture of androids who no longer respect the orders of their creator because they realize the inferiority of biological entities. The confrontation of technophiles and technophobes, so typical of American science fiction especially in the 1960s and 1970s, is omnipresent in the series. But this kind of Manichean confrontation between man and machine is often nuanced in Star Trek, since in most cases what Kirk and his crew have to deal with concerns a technological breakthrough gone haywire. In the episode "The Ultimate Computer" (2.53), a galactic genius (an African American!) creates a computer capable of running the Enterprise in lieu of 430 humans; he explains his motivation for such a machine to the apprehensive Dr. McCoy:

You don't understand. You're frightened because you can't understand it. I'm going to show you, I'm going to show all of you. It takes 430 people to man a starship; with this you don't need anyone. One machine can do all those things they send men out to do now. Men no longer need die in space, or some alien world. Men can live and go on to achieve greater things than fact-finding and dying for galactic space, which is neither ours to give or to take. You can't understand. We don't want to destroy life, we want to save it.

Although his intentions are obviously quite noble, unfortunately for him the computer is so smart that it will take over the ship; but not endowed with human qualities of right and wrong and incapable of distinguishing between the simulation of an attack it has been programmed to repel and reality, it proceeds to destroy other starships because it believes the Enterprise is actually being attacked. Only Kirk's human intelligence will save his ship and crew from disaster by convincing the computer to self-destruct because it has murdered its creator. Yet another example is the episode "A Taste of Armageddon" (1.23), in which Kirk and his landing party discover a civilization locked in a 500-year-long war waged by master computers which make virtual hits on cities and send millions of inhabitants to "disintegration chambers" to die, based on print-outs of virtual casualties. Kirk manages to destroy the computers and provoke a real war, in the hopes 
that the horrors of actual warfare and collateral damage will bring the whole affair to an end.

The technotopias of the Star Trek future focus particularly on the question of what it means to be human, both in positive and negative terms. This theme is conveyed first and foremost through the vector of the Mr. Spock character, an alien among humans who is not only extremely observant but also very cynical in his evaluations of humanity and its violent history of which he reminds Kirk, and the audience, on a regular basis. Several episodes treat the theme of the android, such as "What Are Little Girls Made Of?" (1.7) or "I, Mudd" (2.37). In "I, Mudd", the androids not only promise humans immortality (thanks to the transfer of their brains into an android body) but are also programmed to serve humans so well that the humans will lose their desire for agency. In the following dialogue, the "head" android, Norman 1, reveals his true intentions to the mercenary Harry Mudd whom the androids (identified by a first name and a number, in this scene Norman 1, Alice 1 and Alice 99) have treated thus far as their master:

NORMAN 1. Our role is to serve.

MUDD. That's exactly what I'm saying, put my bags on the ship.

KIRK. Harry, I think they have something else in mind.

NORMAN 1. You are correct, Captain. Harry Mudd is flawed, even for a human being. We recognized this from the beginning but used his knowledge to obtain more specimens. Your species is self-destructive, you need our help.

KIRK. We prefer to help ourselves. We make mistakes but we are human, and maybe that's the word that best explains us.

NORMAN 1. We will not harm you, but we will take the starship and you will remain on this planet.

MuDD. Now look here, you can't do that! Now listen: to serve us, you must obey us.

ANDROIDS [in unison]. No, my Lord Mudd.

MuDD. Alice Number One, obey me, put my bags on that ship! [She shoves him and he falls.]

NORMAN 1. We cannot allow any race as greedy and corruptible as yours to have free run of the galaxy.

SPOCK. I'm curious, Norman. Just how do you intend to stop them?

NORMAN 1. We shall serve them. Their kind will be eager to accept our service. Soon they will become completely dependent upon us.

ALICE 99. Their aggressive and inquisitive instincts will be under our control.

NORMAN 1. We shall... take care of them.

SPOCK. Eminently practical.

KIRK. The whole galaxy, controlled by... your kind?

NORMAN 1. Yes, Captain, We shall serve them and you will be happy... and controlled. [Dramatic music ends the scene.]

Here is the crux of the utopian dream itself: men can only be happy if conditioned to be so, and controlled by some form of authority 
ensuring happiness at all costs. In fact, we can, for all intents and purposes, consider that the androids of "I, Mudd" are just an upgraded version of Big Brother, or of other machines built and used to contain human agency in technotopia. This particular episode exposes, in fact, the dialogue of technophiles and technophobes in American science fiction of the period, which will later be best illustrated in Hollywood SF movies such as 2001, A Space Odyssey (in particular the computer HAL) or Westworld ${ }^{8}$.

Where, then, is utopia to be found in Star Trek, we may wonder? It is through the United Federation of Planets and its representatives - the captain and crew of the U.S.S. Enterprise - that the universal values of humanism are carried across the galaxy. As I have already developed somewhat in my previous article on the series (see footnote 1), the captain and his crew embody the concept of multiracialism which goes beyond the human race itself: although Kirk, McCoy and "Scotty" are white Anglo-Saxon males, Uhura is African (American?), Sulu is Japanese-American and Chekov, although white, is Russian. The "addition" to this mixture is the presence of the halfbreed alien Spock who is Vulcan by his father and human by his mother; and the episode "Plato's Stepchildren" (3.65) shows the first televised inter-racial kiss - originally aired on November $22^{\text {nd }}, 1968^{9}-$ between Kirk and Uhura. Generally speaking, Captain Kirk reprimands any form of intolerance to the different races and cultures which may be exhibited by his crew when various encounters occur, notably for example in "The Balance of Terror" (1.14): in this episode, when the Enterprise crew sees Romulans for the very first time, the Romulans' almond-shaped eyes and pointy ears seem to indicate that the Romulan and Vulcan races are the same (one cannot help but compare this to the Western notion that all Asian races "look the same"). This will lead some of the bridge crew to view Spock as belonging to a "traitorous race" and accuse him of being a Romulan spy.

The Enterprise as the seed of Federation utopia represents one of the leitmotivs of the series, significant in a period of racial conflict in the United States, and of the escalation of violent confrontation emanating from the radicalization of students, minorities and women, especially in 1968 and 1969, the height of the anti-war movement. The episode entitled "Let That Be Your Last Battlefield" (3.70, originally aired January $10^{\text {th }}, 1969^{10}$ ) addresses the question of racial hatred

\footnotetext{
8 20o1, A Space Odyssey (dir. Stanley Kubrick, 1969) and Westworld (dir. Michael Crichton, 1973). I am indebted to Mehdi Achouche for these examples which are more fully developed in his Ph.D. dissertation, "Utopisme technologique dans la science-fiction hollywoodienne, 1982-2010: Transhumanisme, posthumanisme et le rêve de 'l'hommemachine", defended on 9 December 2011 at the University of Grenoble 3.

${ }^{9}$ Source: http://en.wikipedia.org/wiki/List of Star Trek: The Original Series episodes accessed 29 November 2011.
}

${ }^{10}$ Ibid. 
openly. The opening events of the episode can be summed up as follows:

On stardate 5730.2, the Enterprise is on a mission [...] when sensors track a Federation shuttlecraft reported stolen from Starbase 4. The craft is disabled and brought aboard along with its strange alien pilot who is found injured and taken to sickbay. The man later awakens and identifies himself as Lokai - a political refugee from the planet Cheron who requests asylum. Lokai's most striking feature is that his skin is half black and half white, the two halves split perfectly down the center of his body. His unique physiology is explained by Mr. Spock as possibly being "one of a kind."

Shortly thereafter, sensors detect another spacecraft in fast pursuit of the Enterprise. Curiously, the craft remains invisible to all but sensors and sets itself on a direct collision course with the ship. Moments later, Spock reports the invisible craft has disintegrated and deposited an "alien presence" aboard the ship. Kirk turns to see the alien pilot who has beamed himself directly to the bridge. The second alien identifies himself as Bele.

Like Lokai, Bele is half black and half white, with the color divided by a line through the exact center of his face. However, the sides of Bele's black and white skin are reversed from those of Lokai ${ }^{11}$.

When Bele is allowed to visit Lokai in the sickbay, the dispute between the two aliens unveils the reasons for their mutual hatred. Lokai is the leader of a failed revolution against the "master race" which Bele represents:

LOKAI. I will not return to Cheron with him, to a land of murdering oppressors!

KIRK. I told you where you're going. I allowed your fellow countryman here simply as a courtesy.

BELE. And you see how this killer repays you, as he repays all his benefactors.

LOKAI. Benefactors! He's a liar! He raided our homes, tore us from our families, he herded us together like cattle and sold us as slaves!

BELE. They were savages, Captain. We took them into our hearts, our home. We educated them.

LOKAI. Yes, just education enough to serve the master race!

BELE. You were the product of love, and you repaid us with murder!

LOKAI. Why should the slave show mercy to the enslaver?

BELE. Slaves? That was thousands of years ago. You were freed.

LOKAI. Freed? Were we free to be men? To be husbands and fathers?

Free to live in equality and dignity?

The parallels to American history (past and present events) are obvious enough to go uncommented here. But the "twist" added to the issue by Roddenberry is the question of the perception of race itself: Kirk, along with the members of his crew, remains perplexed as to why the two

${ }^{11}$ Source: http://en.wikipedia.org/wiki/Let_That_Be_Your_Last_Battlefield accessed 29 November 2011. 
aliens hate each other when they "look alike". It is Bele who will point out that Lokai, like the rest of his (former slave) race, are white on the right side whereas Bele and his (master) race are black on the right side (see Plate 4), apparently a fundamental difference which has determined their planet's culture for millennia, and is now leading the planet's population to the brink of extinction due to civil war.

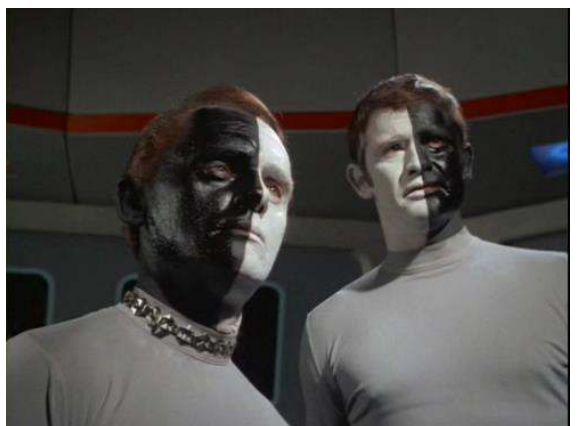

Plate 4: The question of race in "Let That Be Your Last Battlefield" (3.65)

It would seem, then, that racial Otherness is in the eye of the beholder, and that in the utopian society of the Federation this problem has been eradicated, perhaps a commentary as to how America could solve its racial tensions of the moment? This becomes clearer in the closing scene on the bridge, where Kirk lectures the two aliens on the future conduct they must follow while on the Enterprise:

I could put you in the brig for what you've done but I won't do it, because you are new to this part of the galaxy, which is governed by the United Federation of Planets. We live in peace, with full exercise of individual rights. The need to resort to violence and force has long since passed and will not be tolerated aboard this ship. You are free to move about the ship. I hope that you will take the opportunity to learn more about the Federation through its best representatives... my crew.

Thus, through the person of Kirk himself, either in exchanges with his closest friends and officers (Spock, McCoy and Scotty) or with aliens encountered in different episodes as we have seen here, the audience is exposed to the Federation's values of inter-racial unity, individual rights and benevolent non-violent empire-building. In this we witness the didactic purpose of utopian discourse, with the Enterprise as the place of exchange on American values, which we can view as criticism or as a reassertion of Manifest Destiny, depending on how we choose to understand the characters' discourse, plot resolution as well as cultural dimensions in the various episodes of the series. 
As a conclusion, it is possible to say that the utopias of Star Trek are ambiguous at best. This is the result of at least two factors: on the one hand, the very nature of utopia is unstable because "the past contains not only those forces and processes which led to utopia, but also all those disruptive tendencies and disintegrating attitudes which prevent utopia from being realized ${ }^{12}$." On the other hand, the very nature of the American utopian dream in the context of the 1960s counterculture was one of rebellion and rejection of what, until then, had been fundamental values which had structured society. Star Trek attempts to serve as a point of mediation between the contested past and the imagined future through the science fictional tradition of the quest for new frontiers.

\section{Bibliography}

Achouche Mehdi, "Utopisme technologique dans la science-fiction hollywoodienne, 1982-2010: Transhumanisme, posthumanisme et le rêve de 'l'homme-machine", unpublished Ph.D. dissertation, defended on 9 December 2011 at the University of Grenoble 3.

ANDRÉOlLE Donna, “Beam me up Scotty, there's no intelligent life down here': The failed (counter)cultural message of Star Trek, the Original Series (1966-1969)", EOLLE, No.1, 2012, p. 38-46, http://www.univ-lehavre.fr/ulh_services/-Revue-EOLLE-.html.

Dubois Claude-Gilbert, Problèmes de l'Utopie, Paris, Les Archives des Lettres Modernes, 1968.

ELLIOTT Robert, The Shape of Utopia: Studies in a Literary Genre, Chicago, The University of Chicago Press, 1970.

GERBER Richard, Utopian Fantasy: A Study of English Utopian Fiction since the End of the Nineteenth Century, London, Routledge \& Kegan Paul, 1955.

Hamilton Alexander, John JAY and James Madison, The Federalist: A Commentary on the Constitution of the United States, ed. Robert Scigliano, New York, The Modern Library, 2000.

MARX Leo, The Machine in the Garden: Technology and the Pastoral Ideal in America, New York, Oxford University Press, 2000 [1964] (Kindle edition).

${ }^{12}$ Gerber, p. 24. 